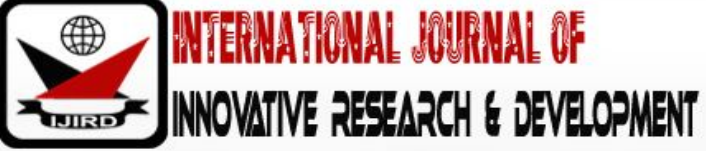

ISSN 2278 - 0211 (Online)

\section{Comparison of Pupils' Academic Performance by Region, in Integrated Science at the Basic Education Certificate Examination, between 2005 and 2007 in Selected Junior Secondary Schools in Sierra Leone}

\author{
Dr. Tamba Kebbie \\ Acting Director, Science Curriculum Development Centre, Njala University, Sierra Leone
}

\begin{abstract}
:
The study compared pupils' academic performance by region in integrated science at the Basic Education Certificate Examination (BECE) in selected junior secondary schools between 2005-2007 in Sierra Leone. Descriptive research of a survey design was adopted. The target population comprised of all the junior secondary schools that were compiled in the Handbook for Junior Secondary Schools in Sierra Leone in 1994, all the junior secondary school pupils that sat to integrated science at BECE in 2005, 2006 and 2007 academic years in Sierra Leone, Integrated Science Teachers and Integrated Science Heads of Department. Out of the population, sample of 100 junior secondary schools, were purposively chosen by the researcher. To ensure representative samples in the four regions, stratified random sampling technique was employed. The main research instrument used to collect data on pupils' performance at BECE within the years under review was the Basic Education Certificate Examination results published by WAEC in 2005, 2006 and2007 academic years. Data were analysed using statistical tools. Firstly, descriptive statistics which entails frequency counts and percentages were used to address the research questions while the Chi- Square statistic was employed to test the Null hypothesis at 0.05 level of significance through Statistical Package of Social Sciences(SPSS) Software. These results were displayed on bar charts and line graphs for meaningful interpretations.

The findings of the study revealed that unsatisfactory performance of candidates in integrated science at BECE between the periods 2005 and 2007across the regions exist, which is deteriorating. This unsatisfactory performance of pupils across these regions is said to be attributed to many factors which is a grave concern to the nation .Based on the findings it was recommended that government through the Teaching Service Commission ensures that well trained and qualified teachers in integrated science with vast experience should be recruited across the regions in Sierra Leone to teach integrated science. This will help to meet the needs of the learners

Furthermore, it was recommended that the teacher training colleges, polytechnics and universities should intensify the training of teachers especially in Science Education pedagogy .Finally, the Ministry of Education should ensure that in each region, infrastructural facilities are been provided to reduce congestion in the classrooms. And there should be a pupil teacher ratio of 1:40 to ensure effective and efficient class management and control.
\end{abstract}

Keywords: Comparison, performance, trend, regions, integrated science, junior, secondary, school

\section{Introduction}

\subsection{Background to the Study}

Education to a nation serves a spring board to higher height leading to better transformation, of the lives of its citizens. It also forms the basis for political, social and economic growth and development of a nation. Sierra Leone before now had an outstanding record of history of education in the West Africa sub-region as it was referred to as the 'Athens' of West Africa. The country maintained this high quality standard of education it inherited from its colonial masters until the 80s.Today, the educational standards in Sierra Leone have dropped considerably. A fall in the educational standards of a nation is a cause for concern to every stakeholder of the nation. This is evident with the poor performance outcome in public examinations including the National Primary School Examination (NPSE), the Basic Education Certificate Examination (BECE) and the West African Senior School Certificate Examination (WASSCE) as reported every year by the Chief Examiners of WAEC. According to Iddi (2016) as cited in Meyer (2008), explained that access to quality basic education, is a fundamental human right for every child. On that note, children all over the world have the civic right to have access to education that prepares them for social integration and economic freedom. This is confirmed by Basic Education Coalition (2013) which stated that education could be seen as a right that exposes individual to social advancement. 
In the 6-3-3-4 system of education, the first six years comprised primary education followed by three years of junior secondary education for all primary school graduates. This 6-3 block (a total of 9 years) make up the formal part of the Basic Education. On completion of the academic work of the junior secondary school, the pupils take the second public national examination referred to as the Basic Education Certificate Examination (BECE), which together with their continuous assessment profiles, determine whether they will continue their education at general or specialist senior secondary schools or proceed to Technical and Vocational Schools of varying course contents and duration.

Pupils who go through the first level ' 6 ' of the system,, take a summative examination, referred to as the National Primary School Examination(NPSE) conducted by the West African Examination Council (WAEC).Successful candidates in this examination enter the next level ",3" of the system. At this level the pupils go through three year schooling of the junior secondary school. Subjects offered at this level are classified as either "Core" or "Elective". This division is to distinguish between those subjects which are regarded as the foundation stones of a literate and numerate individual in present day Sierra Leone (core subjects), and those subjects (electives) which build on this foundation. Both core subjects and electives are essential for achieving the desired educational goals of the country.

Subjects offered at the junior secondary school include: mathematics, social studies, integrated science language arts, religious and moral education, introduction to technology, electronics, creative practical arts, physical and health education agriculture and the Sierra Leonean Languages (Krio, Mende, Themne and Limba).At the third year of the JSS, the pupils offer four core and four electives subject in their final examination,(BECE).The West African Examination Council (WAEC) serves as a reputable council that conducts three categories of examinations. These include the national examinations, international examinations and examinations administered on behalf of other Examining Boards.

In the final assessment of candidates BECE, grades scored by candidates fall within the range of aggregate 6 to 42. The final grades scored by each candidate are first expressed in percentage and later put into ranges that are further converted to Grades 1 - 7 based on the acceptable ranges by WAEC. In computing the final grade to get the final aggregate all grades scored in the core subjects are taken into consideration. Better grades (1-6) from two of the electives are also considered. The total of the grades scored in the four core subjects and the two elective subjects give the final aggregate score of each candidate.

Schools usually determine the aggregate required to gain admission into the SSS1. Most grade A schools accept aggregate ranging from grade 6-25 for admission into SSS1, Grade B schools accept aggregate between 6-30 for admission, pupils with aggregates ranging between 30-39 are generally accepted in Grade C schools.

Pupils' integrated science achievement from the JSS serves as a predictor of later achievement in biology, chemistry and physics. This is confirmed by a study carried out by Osokoya (1999) which revealed that students' score in integrated science predicted later achievement in biology, chemistry and physics. This shows the relevance of integrated science in the JSS curriculum. Different grades are used to denote the achievement level in the JSS subjects. These grades are categorized as follows: Grade 1- Excellent; Grade 2- Very Good; Grade 3- Good; Grade 4-Credit; Grade 5- Credit; Grade 6- Pass; Grade 7- Fail (GOSL, 1994).

Academic performance is very important in education. The thrust of any country for it development rest on education. Adedeji(1998), asserted that students' performance appears to be the major focus by which the success of any educational institution could be judged. The performance of students in any subject could be determined by multidimensional related factors which include the principal, teachers, pupils' parents and learning environment to name but a few.

George (2001) from his findings in a survey explained that the performance of students depends on a number of different factors. Oduru (2000) asserted that BECE provides an excellent opportunity to assess the performance of the basic school system, and that this form of education helps to determine the individual's academic ability and further reveals how this skill should be progressed on their next stage of their academic pursuit.

\subsection{Statement of the Problem}

In the 6-3-3-4 system of education, at the end of the '3-3' block of the system, pupils are allowed to take the Basic Education Certificate Examination of the first ' 3 ' of the system of education. Subjects offered at the BECE, serve as foundation or bedrock for subjects offered at the Senior Secondary School. Integrated Science is one of the core subjects offered at the BECE.As a subject of integration, pupils who score better grades (1-4) in it, together with Mathematics, Language Arts, Electronic/ Technology, Agriculture, Physical and Health Education, are allowed to enter the science stream of the senior secondary school to offer subjects like physics, chemistry, biology, mathematics, core science and further mathematics.

This shows the relevance of integrated science to pupils in the science stream. It has been observed by various researchers that performances of pupils in mathematics, integrated science had been very poor at the BECE. As a result of poor performance, pupils are not allowed to pursue subjects in the science stream rather; they opt for the Arts and Commercial streams. The issue of performance is also confirmed by Ofoegbu (2004) who linked poor performance of students to poor teachers' performance in terms of accomplishing the teaching task, negative attitudes to work and poor teaching habits which have been attributed to poor motivation. This is also in line with Adane (2003) as cited in Lockheed and Vers poor (1991) that lack of motivation and unprofessional commitment on the part of the teachers produce poor unprofessional attitude towards pupils which in turn affect the performance of students academically. It is against this backdrop that the researcher compared pupils' academic performance by region in integrated science at the Basic Education Certificate Examination in 2005, 2006 and 2007 in selected junior secondary in Sierra Leone. 


\subsection{Research Questions}

The following research questions were raised:

- Research Question 1: What is the regional performance of pupils in integrated science at BECE in 2005?

- Research Question 2: What is the regional performance of pupils in integrated science at BECE in 2006?

- Research Question 3: What is the regional performance of pupils in integrated science at BECE in 2007?

- Research Question 4: What is the trend analysis of pupils' performance in integrated science at BECE in

- Research Question 5: What is the regional trend analysis of the performance of pupils in integrated science at BECE in 2005, 2006 and 2007?

\subsection{Research Hypothesis}

- $\mathrm{H}_{01}$ : There is no significant difference in the number of passes (grades 1-6) in integrated science at BECE across the regions of Sierra Leone between 2005 and 2007.

\section{Methodology}

The study compared the performances of pupils by region in integrated science at BECE in selected junior secondary schools between 2005 and 2007 in Sierra Leone. The researcher adopted the following procedures under this section: research design, study area, population, sample and sampling technique, research instrument, data collection procedure and data analysis.

\subsection{Research Design}

The study is a descriptive type of a survey design, it compared performance of pupils by region in integrated science. The study used descriptive survey design, which is the systematic collection of data in standardized form from an identifiable population or representative (Oso and Onen, 2009).It involved the systematic collection of data and summaries, which provided a general picture of regional comparison of the performances of pupils in integrated science at According to Gay (1996), descriptive research is a research type with specific nature of a given phenomenon. It determines and report the way things are. It involves collecting data in order to answer to research questions concerning the current state of the subject of study. Looking at the descriptive research, its survey focuses on determining the status of a defined population with respect to certain variable.

\subsection{Study Area}

The study is delimited to regional comparison of pupils' performance in integrated science at BECE between 2005 and 2007 in Sierra Leone. The study area covered the four regions in Sierra Leone : Northern, Southern, Eastern Regions and the Western Area. Sierra Leone lies on the West Coast of Africa between $6{ }^{\circ} 55^{\prime} \mathrm{N}$ and $10^{\circ} 00^{\prime} \mathrm{W}$. The republic of Guinea borders it on the North and North East while the republic of Liberia borders it in the East and South East on the West and South West, the Atlantic Ocean extends approximately 340km.According to the 2014 Census, Sierra Leone is with a population of about 7 million. It has sixteen ethnic groups, with the Mende, Limba and Themne ethnic groups in dominance. The major economic activities of the inhabitants of the study area are business, mining, agriculture and white collar jobs.

\subsection{Target Population of the Study}

Mugenda and Mugenda (2003) defines target population as members of a real or hypothetical set of people, events or objects the researcher wishes to generalize the results of the research.. The target population of the study included all the 200 junior schools found in the Handbook of Junior Secondary Schools published by the Government of Sierra Leone in 1994, all the JSS pupils that were presented for the 2005, 2006 and 2007 BECE in integrated science, integrated science teachers, integrated science heads of department of JSS in Sierra Leone.

\subsection{Sample and Sampling Technique}

Out of the population of schools, the researcher used purposive sampling strategy to select a sample size of 100 junior secondary schools in Sierra Leone that comprised of purely boys' schools, purely girls' schools and co-educational schools. To ensure representativeness, the $100 \mathrm{JSS}$ were randomly distributed in the four regions using stratified random sampling technique. This is done by dividing the number of schools in each region divided by the population of the schools (200) and multiplied by the chosen sample to determine the sample size of each region. The calculation is shown thus:

- $\quad$ Total number of schools $=200$

- No. of schools in the Northern Region $=60$

- No. of schools in the Southern Region $=50$

- No. of schools in the Eastern Region $=54$

- No. of schools in the Western Area $=36$

Sample size calculation for each region

Northern Region $=\underline{60} \times 100=30 \%$ of the 100 schools to be selected

200 schools

100

$\underline{30} \times 100$ schools $=30 \mathrm{JSS}$

Sample size for Northern Region

$$
=30 \text { J.S.S. }
$$


Sample size for Eastern Region $=\underline{54} \times 100=27 \%$

200 Schools

$\underline{27} \times 100$ schools $=27$ J.S.S.

100

Sample size for Eastern Region

$$
=27 \text { J.S.S. }
$$

Sample size for Southern Region $=\underline{50} \times 100=25 \%$ 200schools

$\underline{25} \times 100$ schools $=25$ J.S.S.

100

Sample size for Southern Region

$$
=25 \text { J.S.S. }
$$

Sample size for Western Area $=\underline{36} \times 100=18 \%$

200schools

100

$\underline{18} \times 100$ schools $=18 \mathrm{JSS}$

Sample size for the Western Area

$=18$ J.S.S.

\subsection{Research Instruments}

The main research instrument used for the study was results of the scores obtained by pupils in integrated science at BECE in 2005, 2006 and 2007 academic sessions in Sierra Leone. These BECE results were obtained from WAEC National Headquarters, Tower Hill in Freetown.

\subsection{Data Collection Procedure}

A letter was written to the Head of the Research Department at WAEC through the Head of the National Office to permit the researcher to access the results of the pupils that sat to the BECE in integrated science in 2005, 2006 and 2007 academic years. The grades obtained by pupils of the selected schools in all the districts of each region were taken into consideration. The grades obtained were put into two categories: passes (grades 1-6) and failures (grade 7). The data were collected by the researcher himself.

\subsection{Data Analysis}

The data collected were analysed using different statistical tools. Firstly, for the research questions identified, the statistical tool used was descriptive statistics. The data or raw scores were first processed into frequency counts and later converted into percentages of their totals. Secondly, to test the null hypotheses at $0.05 \%$ significance level, the statistical tool the researcher used was the chi-square statistic through the formula $\mathrm{X}^{2}=(0-\mathrm{E})^{2}$

Where $\mathrm{X}^{2}=$ Chi-square

$\mathrm{O}=$ Observed value

$\mathrm{E}=$ Expected value

The results obtained were graphically displayed on bar charts and line graphs to give clear picture of the findings of the study. Statistical Package for Social Sciences(SPSS) software was used for analysis.

\section{Results and Discussions}

\subsection{Research Question 1}

\subsubsection{What is the Regional Performance of Pupils in Integrated Science at BECE in 2005?}

The study sought to find answer to the regional performances of pupils in integrated science at BECE in 2005.As indicated in Table 1, it could be observed that in the four regions of Sierra Leone, pupils from the selected schools in the Eastern Region and Western Area performed better when compared to their counterparts in the Northern and Southern Regions. According to the table, of the Eastern Region, there were (54.98\%) passes followed by the Western Area (53.06\%) passes.

The overall performance of pupils in integrated science in 2005 BECE was satisfactory, with 20,012 candidates that attempted the exam, (51.11\%) passed and (48.89\%) failed. This implies that much effort was made by the pupils in 2005 BECE though the performance was on average 


\begin{tabular}{|c|c|c|c|c|c|c|}
\hline Region & $\begin{array}{c}\text { No. Sat to } \\
\text { Exam }\end{array}$ & $\begin{array}{c}\text { No. } \\
\text { Absent }\end{array}$ & $\begin{array}{c}\text { No. of } \\
\text { Passes }\end{array}$ & Percentage & $\begin{array}{c}\text { No. of } \\
\text { Failures }\end{array}$ & Percentage \\
\hline Northern & 4139 & 30 & 1941 & 46.90 & 2198 & 53.10 \\
\hline Southern & 3574 & 24 & 1667 & 46.64 & 1907 & 53.36 \\
\hline Eastern & 4905 & 50 & 2697 & 54.98 & 2208 & 45.02 \\
\hline $\begin{array}{c}\text { Western } \\
\text { Area }\end{array}$ & 7394 & 96 & 3923 & 53.06 & 3471 & 46.94 \\
\hline Total & 20,012 & 200 & 10,228 & 51.11 & 9784 & 48.89 \\
\hline
\end{tabular}

Table 1: Frequency distribution of performances in Integrated Science in

2005 BECE of the Selected Junior Secondary Schools by Region in Sierra Leone

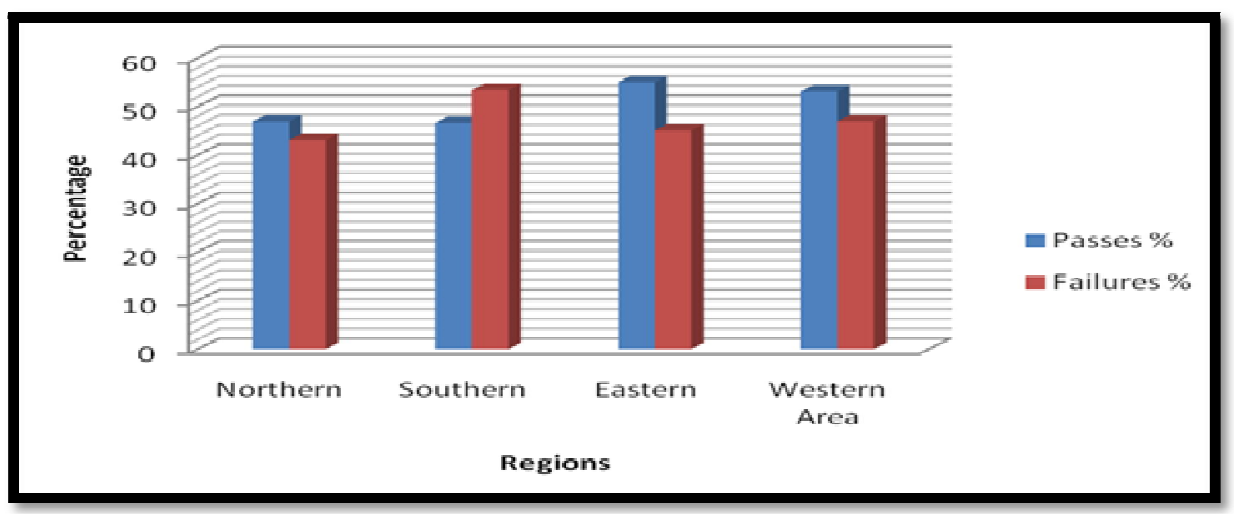

Figure 1: Bar Chart Showing Comparative Analysis of Performances in Integrated Science in the 2005 BECE of the Selected Junior Secondary Schools by Region in Sierra Leone

\subsection{Research Question 2}

\subsubsection{What is the Regional Comparative Performance of Pupils in Integrated Science at BECE in 2006?}

The study sought to find answer to the regional performances of pupils in integrated science at BECE in 2006. As revealed in Table 2, pupils in the selected JSS in the Western Area performed better, compared to the pupils in the other regions with (57.92\%) passes followed by the pupils in the Eastern Region with (52.81\%) passes. The pupils of the Southern Region had the highest percentage (53.16\%) failure in integrated science. This implies that in 2006, performance of pupils in integrated science was satisfactory.

\begin{tabular}{|c|c|c|c|c|c|c|}
\hline Region & $\begin{array}{c}\text { No. Sat to } \\
\text { Exam }\end{array}$ & No. Absent & No. of Passes & $\begin{array}{c}\text { Percentage } \\
\mathbf{\%}\end{array}$ & $\begin{array}{c}\text { No. of } \\
\text { Failures }\end{array}$ & $\begin{array}{c}\text { Percentage } \\
\mathbf{\%}\end{array}$ \\
\hline Northern & 5813 & 103 & 2864 & 49.27 & 2949 & 50.73 \\
\hline Southern & 3975 & 39 & 1862 & 46.84 & 2113 & 53.16 \\
\hline Eastern & 6254 & 70 & 3303 & 52.81 & 2951 & 47.19 \\
\hline Western Area & 7181 & 14 & 4159 & 57.92 & 3022 & 42.08 \\
\hline Total & 23,223 & 226 & 12,188 & 52.48 & 11,035 & 47.52 \\
\hline
\end{tabular}

Table 2: Comparative Analysis of Performances in Integrated Science in the 2006 BECE of the Selected Junior Secondary Schools by Region in Sierra Leone

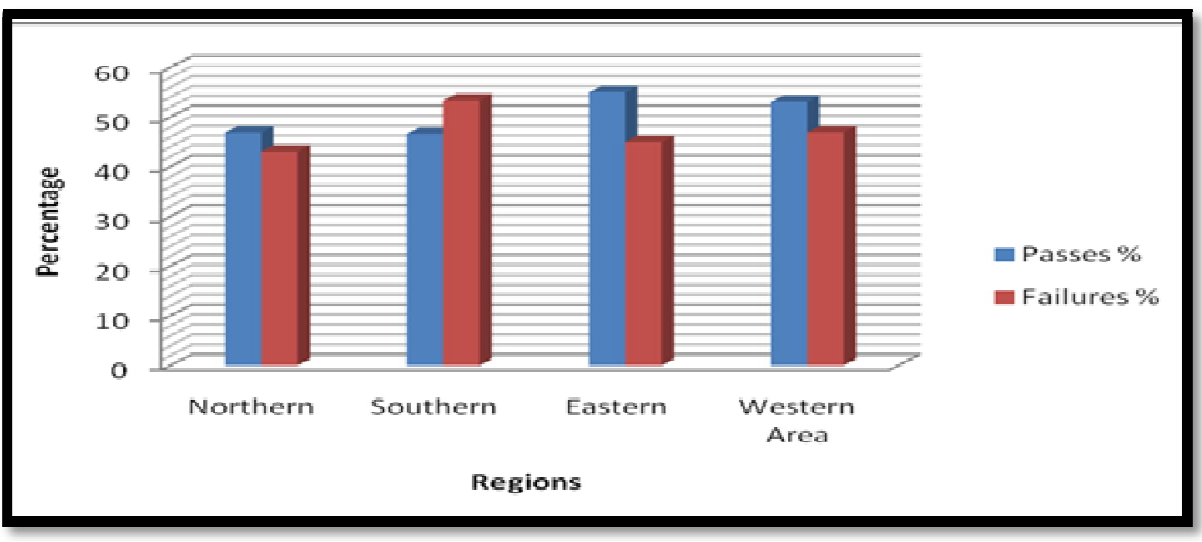

Figure 2: Bar Chart Showing Comparative Analysis of Performances in Integrated Science in the 2006 BECE of the Selected Junior Secondary Schools by Region in Sierra Leone 


\subsection{Research Question3}

\subsubsection{What is the Regional Comparative Performance of Pupils in Integrated Science at BECE in 2007?}

The study sought to answer question on the regional comparative performance of pupils in integrated science in 2007 BECE.As illustrated in Table 3, performances of pupils in integrated science in 2007 BECE by region shows that pupils of the selected schools in the Western Area performed better than their counterparts in other regions when compared, with (58.40\%) passes. It could be also deduced from the table that pupils of the selected schools in the Eastern Region performed worst with (61.92\%) failures. By implication, the performance in integrated science 2007 in Sierra Leone was deteriorating.

\begin{tabular}{|c|c|c|c|c|c|c|}
\hline Region & $\begin{array}{c}\text { No. Sat to } \\
\text { Exam }\end{array}$ & No. Absent & $\begin{array}{c}\text { No. of } \\
\text { Passes }\end{array}$ & \% & $\begin{array}{c}\text { No. of } \\
\text { Failures }\end{array}$ & \% \\
\hline Northern & 6958 & 56 & 3034 & 43.60 & 3924 & 56.40 \\
\hline Southern & 4513 & 22 & 2149 & 47.72 & 2364 & 59.26 \\
\hline Eastern & 7145 & 53 & 2721 & 38.08 & 4424 & 61.92 \\
\hline Western Area & 7639 & 26 & 4461 & 58.40 & 3178 & 41.60 \\
\hline Grand Total & 26,255 & 157 & 12,365 & 47.10 & 13,890 & 52.90 \\
\hline
\end{tabular}

Table 3: Comparative Analysis of Performances in Integrated Science in the

2007 BECE of the Selected Junior Secondary Schools by Region in Sierra Leone

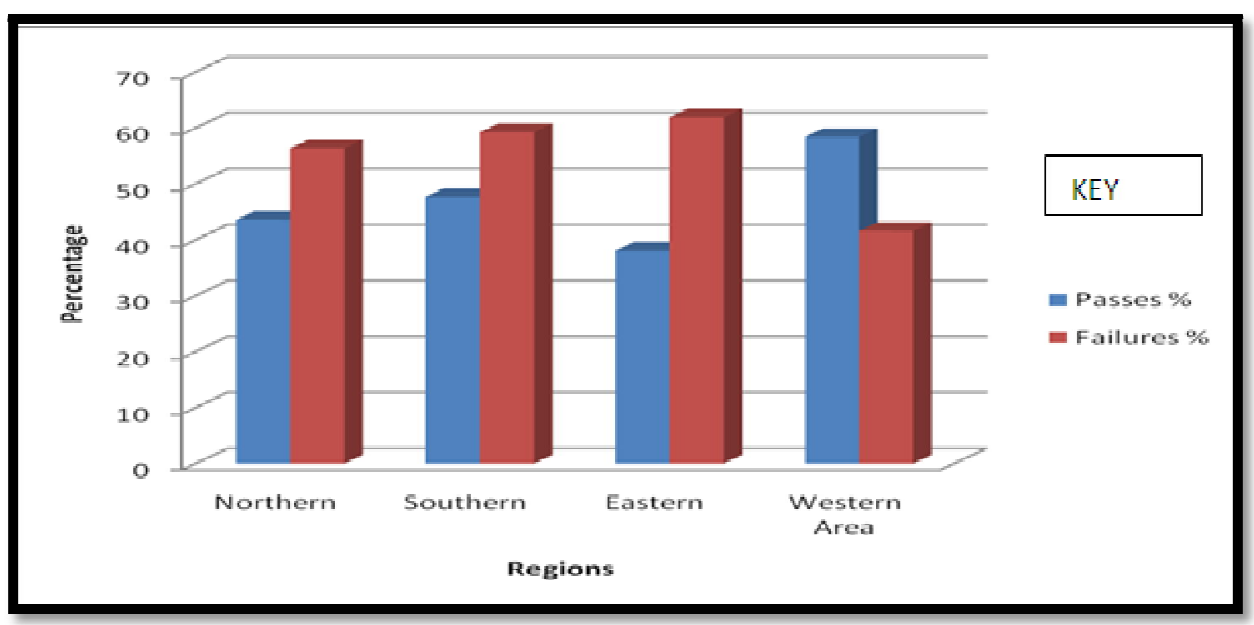

Figure 3: Bar Chart Showing Comparative Analysis of Performances in Integrated Science at BECE 2007 of the Selected Junior Secondary Schools by Region in Sierra Leone

\subsection{Research Question 4}

3.4.1. What is the Trend Analysis of Performance of Pupils in Integrated Science in the Selected Schools at BECE in 2005, 2006 and 2007?

The study sought to find answer to the trend of academic performance of pupils in integrated science at BECE in the selected schools in 2005, 2006 and 2007.As revealed in Table 4, the performance of pupils in integrated science at BECE in 2006 was better when compared to performance of pupils in 2005 and 2007. A total of 23,223 pupils attempted the exam, 12,188 (52.48\%) passed. The performance in 2007 was unsatisfactory with 26,255 candidates that attempted the exam, 12,365 (47.10\%) passed. It could be observed that there was always increase in enrollment of pupils in each of the years under review. This study is in line with a survey undertaken by Okere-Darko(2011) in Ghana w confirmed that in 2008, 338,292 candidates sat to BECE nationwide and the number that obtained the required grades for placement in the next institution, was 210,282 representing $61.2 \%$ of the total candidates, in 2009, 395,649 sat to the exam, only $50.2 \%$ passed while in $2010,49.1 \%$ passed and in 2011, 46.9\% passed respectively. Trend assessment is necessary in the educational system. It gives guide as to the effort manifested by both the teacher and the learner in the teaching/learning process.

\begin{tabular}{|c|c|c|c|c|c|c|}
\hline Year & $\begin{array}{c}\text { No. Sat to } \\
\text { Exam }\end{array}$ & No. Absent & $\begin{array}{c}\text { No. of } \\
\text { Passes }\end{array}$ & $\begin{array}{c}\text { Passes } \\
\text { \% }\end{array}$ & $\begin{array}{c}\text { No. of } \\
\text { Failures }\end{array}$ & $\begin{array}{c}\text { Failures } \\
\text { \% }\end{array}$ \\
\hline 2005 & 20,012 & 200 & 10,228 & 51.11 & 9784 & 48.89 \\
\hline 2006 & 23,223 & 226 & 12,188 & 52.48 & 11,035 & 47.52 \\
\hline 2007 & 26,255 & 157 & 12,365 & 47.10 & 13,890 & 52.90 \\
\hline Total & 69,490 & 583 & 34,781 & 50.05 & 34,709 & 49.95 \\
\hline
\end{tabular}

Table 4: Trend Analysis of Performance in Integrated Science at BECE in the

Selected Junior Secondary Schools in Sierra Leone in 2005, 2005 and 2007 


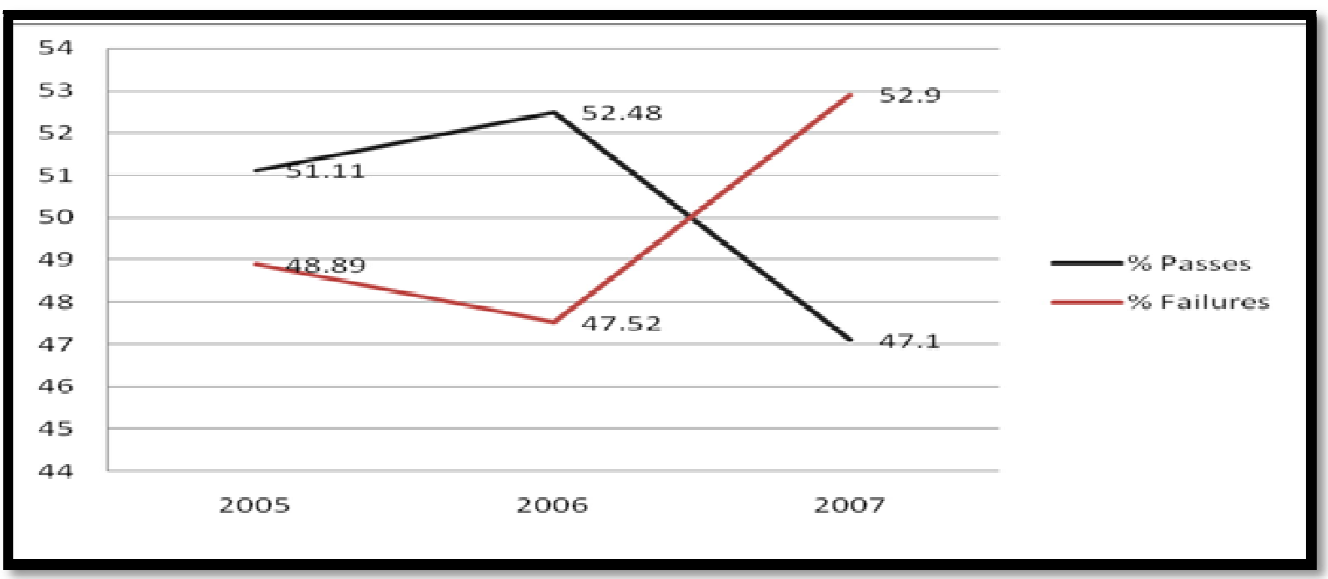

Figure 4: Line Graph Showing Trend Analysis of Performance in Integrated Science at BECE in the Selected Junior Secondary Schools in Sierra Leone between 2005 and 2007

\subsection{Research Question 5}

\subsubsection{What is the regional Trend Analysis of Performance of Pupils in Integrated Science at BECE in the Selected Schools} in 2005, 2006 and 2007?

The trend of performance of pupils in the three year period shows how satisfactory or unsatisfactory the pupils have performed in the four regions of Sierra Leone. As indicated in Table 5, the trend analysis of performance of the pupils in the selected schools in the Northern Region indicates that there is inconsistency. In 2005, 46.90\% passed in integrated science while in 2006, 49.27\% passed which indicates $2.37 \%$ increase in the passes when performance in 2005 and 2006 are compared. In 2007 it was observed that there was very low percentage $(43.60 \%)$ passes, indicating that the trend analysis of performance of the pupils in integrated science in the Northern in 2006, was discouraging. For the Southern Region according to the table, there is increase in the percentage passes every year (46.64\%, $46.48 \%$ and $47.72 \%)$ though percentage increase is very low.

Furthermore, the table reveals that in the Eastern Region, the percentage passes for 2005 and 2006 was on average but there was decrease in percentage passes, when performance in 2005 and 2006 are compared. In 2007 according to the table, there was a downward trend in performance which indicates a very unsatisfactory performance. Performance in the Western Area as seen in the table shows that pupils that sat to integrated science in 2005, 2006 and 2007respectively did very well in the three-year exams though the performance was on average, they continued to maintain their passes percentage for the three-year period.

Summarily, it is deduced from the table that in between 2005 and 2007 the selected schools in the Western Area and schools in the Eastern Region in 2006 performed well in integrated science when the regions are compared. Trend in performance is confirmed by the assertion of Adu and Ohati (2014)who from their findings revealed that there is always need to continuously assess the trends in the performance of students. The implication to this is to ensure that the lapses are addressed.

\begin{tabular}{|c|c|c|c|}
\hline Region & 2005 & 2006 & 2007 \\
\hline Northern & Passes $=46.90 \%$ & Passes $=49.27 \%$ & Passes $=43.60 \%$ \\
& Failures $=53.10 \%$ & Failures $=50.73 \%$ & Failures $=56.40 \%$ \\
\hline Sourthern & Passes $=46.64 \%$ & Passes $=46.84 \%$ & Passes $=47.72 \%$ \\
& Failures $=53.36 \%$ & Failures $=53.16 \%$ & Failures $=52.28 \%$ \\
\hline Eastern & Passes $=54.98 \%$ & Passes $=52.81 \%$ & Passes $=38.08 \%$ \\
& Failures $=42.02 \%$ & Failures $=47.19 \%$ & Failures $=61.92 \%$ \\
\hline Western Area & Passes $=53.06 \%$ & Passes $=57.92 \%$ & Passes $=58.40 \%$ \\
& Failures $=46.94 \%$ & Failures $=42.08 \%$ & Failures $=41.60 \%$ \\
\hline
\end{tabular}

Table 5: Regional Trend Analysis of Performance of Pupils in Integrated Science at BECE in 2005, 2006 and 2007

\subsection{Research Hypothesis}

- $\mathrm{H}_{01}$ : There is no significant difference in the number of passes in Integrated Science across the regions in Sierra Leone between 2005 and 2007. 


\begin{tabular}{|c|c|c|c|c|c|c|}
\hline \multirow[t]{2}{*}{ Year } & \multicolumn{4}{|c|}{ Region } & & \multirow{2}{*}{$\begin{array}{c}\mathbf{X}^{2} \\
\text { chi-square }\end{array}$} \\
\hline & $\mathrm{R}_{1}$ & $\mathrm{R}_{2}$ & $\mathrm{R}_{3}$ & $\mathrm{R}_{4}$ & Total & \\
\hline $\begin{array}{c}\text { Observed Value } \\
2005\end{array}$ & 1941 & 1667 & 2697 & 3923 & 10228 & 79.1 \\
\hline Expected Value & (2305) & (1670) & (2565) & (3689) & & \\
\hline $\begin{array}{l}\text { Observed Value } \\
2006\end{array}$ & 2864 & 1862 & 3302 & 4159 & 12188 & 46.0 \\
\hline Expected Value & (2747) & (1990) & (3056) & (4395) & & \\
\hline $\begin{array}{c}\text { Observed Value } \\
2007\end{array}$ & 3034 & 2149 & 2721 & 4461 & 12365 & 76.7 \\
\hline Expected Value & $(2787)$ & $(2019)$ & $(3100)$ & $(4459)$ & & \\
\hline TOTAL & 7839 & 5678 & 8721 & 12543 & 34781 & \\
\hline
\end{tabular}

From the $\mathrm{X}^{2}$ tables, the critical value at 5\% level of significance with six degrees of freedom $48 \%$ passes is 12.59 . The observed $\mathrm{X}^{2}$ statistic for the three years are: 79.1, 46.0 and76.7, all of which are greater than the $\mathrm{X}^{2}$ value of 12.59, as a result, the null hypothesis is rejected that, there is no significant difference in the number of passes in integrated science across the regions between 2005, 2006 and 2007 and accept the alternative hypothesis that there is significant difference in the number of passes in integrated science across the regions between 2005, 2006 and 2007.

\section{Conclusion}

Based on the findings, the study concluded that performance in integrated science across the regions was awful. The study concluded that in 2005 there was unsatisfactory performance with only 54.98\% passes from the Eastern Region. The study further concluded that in 2006 performance of pupils in the selected schools had satisfactory performance though the selected schools from Bo had the highest percentage failures (53.16\%). In 2007, the general performance of the selected schools was deteriorating with only schools in the Western Area that performed better and worst were schools in the Eastern Region. In terms of trend analysis performance, of the selected schools in the years of investigation, the study revealed that performance of pupils in the selected schools in 2006 was better than performances in 2005 and 2007, with a total of 23,223 pupils that attempted the BECE examination in integrated science,12,188 pupils passed representing $52.48 \%$ passes. Finally the study rejects the null hypothesis that, there is no significant difference in the number of passes in integrated science across the regions between 2005, 2006 and 2007.

\section{Recommendations}

Based on the findings, it was established that performance of pupils across the regions was very awful and the study recommended that government through the Teaching Service Commission ensures that well trained and qualified teachers with vast experience should be recruited across the regions in Sierra Leone to teach integrated science. This will help to meet the needs of the learners so that these teachers with their experience in the classroom, they would be able to transform the attitude of the learners under teaching atmosphere for them to have passion for teaching.

Furthermore, it was recommended that, the Teacher Training colleges and universities should intensify the training of teachers especially in science pedagogy. Finally, the Ministry of Education should ensure that in each region, infrastructural facilities are provided to reduce congestion in the classrooms and there should be a teacher- pupil ratio of 1:40 to ensure effective and efficient class management.

\section{References}

i. Adane, L.O. (2013). Factors Affecting low Academic Achievement of pupils in Kemp Methodist Junior High School in Aburi, Eastern Region. MPhil. Thesis, University of Ghana region http:/ / ugspace.ug.edu.gh

ii. Adedeji, S.O. (1998). Resource Utilization and Academic Performance of students in Osun State Vocational Secondary School: An Unpublished Ph, D Thesis University of Ibadan.

iii. Adeyemi, T.O. (2011). A comparative study of pupils' academic performance in public examination in secondary schools in Ondo and Eketi States, Nigeria. Current Research Journal of Economic Theory. 3(2):36-42.

iv. Adu, E.O.,\&Oshati,T.(2014).Psychological Variables as determinants of students' academic achievement in Senior Secondary School Economics in Oyo State, Nigeria. Zimbabwe Journal of Educational Research(ZJER), 26(1);2335

v. Akinkoye, G.M., Adu, K. O., Adu, E.O.(2015).A comparative Analysis of students' performance in Economics in private and public secondary schools in Lagos, Nigeria. Journal of Social Sciences. 44(23):144-151.

vi. Gay, L.R,(1996 ).Educational Research Competencies and Application,(5th edn.).Upper Saddle River, New Jersey. Prentice-Hall Inc. A Simon and Schuster Company,15pp133-145.

vii. George, R.G. (2001). Peer effect, gender and intellectual performance among students at a highly selective college. A social Comparison of abilities analysis 
viii. Government of Sierra Leone (1994). A Handbook for Junior Secondary Schools. Freetown: The Government Printing Department

ix. Iddi, (2016). Acomparative Assessment of the Academic Performance among public and private junior High School in the Tamale Metropolis of Ghana. An M. Sc thesis of the Department of planning, Kwame Nkrumah University and Technology. Kumasi: Department of Planning. Improvement in Nigeria. Gale Group. Retrieved August, 2012 from http;/ / www .ind Articles.com

x. Mugenda, O. M. and Mugenda, A. G. (2003). Research Methods: Quantitative and Quantitative Approaches. AfricanCentre for Technology Studies. Nairobi

xi. Oduro, A.D. (2000). Basic Education in Post reform period. Accra: Centre for policy Analysis (CEPA).

xii. Okyere-Darke, G. (2011). Poor performance of BECE candidates under president Mills. Accra: The Ghana State.

xiii. Oso, W. Y. \& Onen, D. (2009) Writing Research Proposal and Report. Nairobi. Sitima. 